DOI: doi.org/10.18372/38198

UDC: 66:629.73(075.8)

\title{
2.6 INFLUENCE OF ANTIOXIDANTS AND ANTIWEAR ADDITIVES ON JET FUEL PROPERTIES
}

\author{
Sergii Boichenko ${ }^{1}$, Yuri Golych ${ }^{2}$, Anna Iakovlieva ${ }^{3}$, Iryna Shkilniuk ${ }^{3}$, Petro Topilnytskyi ${ }^{4}$, \\ Victoriia Romanchuk ${ }^{4}$, Olufemi Babatunde ${ }^{3}$
}

Production of fuels for aviation engines is one of the developing directions of the oil refining industry. First of all, this is due to the increased number of aircrafts in the world. According to the Forecast International marketing company data, 5835 large air liners and transport planes were built in the world during 2004-2013. Today, according to World Air Fleet data [1], there are about 2,000 airlines in the world which are using 50,000 airplanes. Airlines of the world were transported about 2.5 billion passengers. According to Boeing's data [2], passenger transportation increases annually by $5.1 \%$, and cargo traffic (expressed in ton-kilometers) - by $5.6 \%$.

According to the analytical site [3], about 875,000 tons of jet fuel are produced and consumed in the world every day. In Ukraine (UPECO consulting company data [4]) the amount of consumed jet fuel is about 300-350 thousand tons per year, the half of which falls on Boryspil State Airport.

The quality of jet fuels in comparison with other petroleum products depends to a large extent on the nature of oil and the boiling range of fractions obtained by atmospheric distillation. Fractions of direct distillation are purified in various ways, depending on the oil composition and the quality specifications.

All jet fuels are divided into two subgroups: direct and thermostable ones. In each subgroup there are 2-3 grades of fuel of different fractional composition: i) fuels of wide-fractional composition; ii) flammable fuels (naphtha-kerosene); iii) fuels of heavy-fractional (kerosenegasoil) composition with high flash point. The following operational properties of jet fuels are accepted: pumpability, evaporation, flammability, combustibility, deposits formation tendency, compatibility with structural materials, frictional, anti-wear, protective, cooling properties and toxicity. Each operational quality is characterized by a set of physico-chemical indicators of quality.

To classify jet fuels it is accepted in the world to use such indices as evaporation (boiling range), flammability (flash point) and pumpability (chilling point). The basic requirements for the fuels quality are formed by the International Air Transport Association (IATA), the American Society for Testing and Materials (ASTM), Directorate of Engine Research and Development (DERD, UK Ministry of Defense jet fuel specification) and the «CheckList» [1].

Oil is the main raw material for the production of aviation fuel, as well as other types of fuel. Traditionally, jet fuels are produced via direct distillation; as well as via cracking processing. Jet fuels are medium-distillate oil fractions with boiling range of $140-280{ }^{\circ} \mathrm{C}$. [5-8].

Fuel of «TC-1» grade may be virgin (most often it is a fraction of sulfuric oil that boils in the range of $140-250{ }^{\circ} \mathrm{C}$ ) or mixed. In the latter case, components after hydrofining or demercaptanization, as well as gas fraction after hydrodewaxing can be added to the straight-run fraction of oil. Hydrofining or demercaptanization are used when the total and sour sulfur content is high, hydrodewaxing is used to improve the low temperature properties of kerosene fractions. From literary sources it is known that hydrofining is used when the content of total and sour sulfur in kerosene distillates does not meet the requirements of the standard, demercaptanization - when only the content of sour sulfur does not meet the standard requirements. Fuel of «TC-1» grade is used as fuel for subsonic and supersonic aircraft with limited flight duration. 
Fuel of RT grade is obtained by hydrofining of a straight-run fraction $135-280{ }^{\circ} \mathrm{C}$ from various oils, as well as by the addition of various additives to the hydrodeparaffined straight-line kerosene fraction. The raw materials for hydrofining are distillates, from which it is impossible to produce «TC-1» due to the high content of total and sour sulfur. When oil distillate is hydrofined, aggressive and unstable compounds containing sulfur, nitrogen and oxygen are eliminated; thermal stability increases and corrosion activity decreases. RT is a thermostable fuel for thermally stressed aircraft engines with an extended duration of supersonic flight. It fully meets the requirements for aviation fuel of the highest quality. Moreover, this aviation fuel is universal, since it can be used for both subsonic and supersonic aircraft.

Modern jet fuels must meet a number of requirements related to the cost-effectiveness, reliability, durability, as well as environmental safety [9].

Reliable and durable operation of the aircraft is ensured if the fuel has a fractional composition, capable of maintaining a stable combustion process in all modes of engine operation and does not form vapor locks in the fuel system during altitude flights; if the fuel and its products of combustion do not cause damage of the fuel system and engine details; if the fuel provides reliable operation of the engine in a wide range of external conditions (temperature, pressure, humidity, etc.).

Economic work of the aircraft is provided when the fuel has a low price, high heat of combustion and high density; has such a chemical and group composition, which guarantees the most complete combustion process, as well as low evaporation during altitude flights and long-term storage.

Environmental safety of fuel is provided in case of its least impact on the environment at all stages of operation (production, transportation, storage, refuelling of the aircraft, direct combustion, etc.).

The main technical requirements for jet fuels are the following:

- high level of evaporation, which provides reliable flammability and completeness of fuel combustion;

- satisfactory low-temperature properties, ensuring reliable pumpability at low temperatures;

- chemical and thermooxidative stability with minimal tendency to form deposits in the fuel system of the engine;

- absence of negative influence on metal and non-metallic details of engine fuel systems, equipment for storage and transportation of fuel;

- high lubricity, eliminating the increased wear of fuel assemblies;

- optimal level of electrical conductivity, which prevents the electrification of fuel and ensures safety during pumping and loading-unloading operations with fuel;

- the absence of toxic components, impurities and additives, the minimum content of sulfurcontaining compounds that form environmentally hazardous combustion products.

The fuel stability, namely chemical stability and thermal oxidative stability, is the most important technical requirement for jet fuels. At elevated temperatures some components of fuel become thermally unstable, resulting in an intense formation of a deposit and increased corrosion activity, which leads to the fuel lines plugging and the plunger wear. This reaction is especially intensive at high temperatures typical of the aircraft fuel system.

Thermal oxidative stability is defined as the oxidation stability with the formation of resinous deposits at elevated temperatures $\left(100-120{ }^{\circ} \mathrm{C}\right.$, subsonic aircraft). Some of resinous deposits are insoluble in fuel and can lead to the filter plugging and engine failure.

Jet fuels must meet the increased requirements for thermal oxidative stability:

- under statistical conditions;

- under dynamic conditions. 
In addition to temperature effect, the thermal oxidative stability of fuel can be affected by metals, which are used for the manufacture of fuel engines: copper, bronze, brass, alloy steels, etc. These metals at high temperatures are the catalysts of fuel oxidation.

The presence of resins in fuel leads to increased formation of deposits. At the same time, the negative role of these substances is revealed only at their certain concentrations, below which the presence of resins increases stability and anticorrosive properties of jet fuels. This inhibitory effect is explained by the presence of some sulfur-, nitrogen- and oxygen-containing compounds in resins.

Sulfur compounds play an important role in the formation of insoluble deposits and other oxidation products in fuels. Resins, carbon deposits and lacquer always contain a large amount of sulfur and oxygen. Partial transition of sulfur compounds from fuel to resins and from resin to solid deposits occurs at low temperatures during long-term storage, as well as at high temperatures for several hours. Sulfur compounds of different classes have different effect on the thermal stability of fuels. The least stable components at elevated temperatures are mercaptans and disulfides. The presence of elemental sulfur in reactive fuels, even at a concentration of $0.001 \%$, contributes to a sharp increase in the fuel corrosion activity.

Along with the corrosion activity and low thermal stability the sulfur compounds are characterized by antioxidant properties, which are clearly observed when the content of these compounds in fuel is low. The antioxidant properties of sulfur compounds, for example sulfides, can be explained by their easy interaction with the formation of hydroperoxides, subsequent destruction and, consequently, the prevention of the oxidation chain reaction development. The removal of nitrogen-containing compounds from fuels contributes to the increase of thermal oxidative stability.

The quality of jet fuels depends on used additives to a large extent. Antistatic and antiwear additives, fuel system icing inhibitors and antioxidants are added to the jet fuels. The main requirement for aviation fuel additives is their high effectiveness, i.e. they should be introduced in small concentrations without worsening the fuel quality relative other indices and retain their properties for a long time both in pure form and in fuel composition. In the world practice the additives quantity and composition must be approved by aircraft builders and engine manufacturers and specified by the relevant developers in the documentation.

In order to increase the chemical and thermal oxidative stability of jet fuels during storage and transportation the antioxidants (oxidation inhibitors) are added. Such additives should be introduced into fuels that undergo a hydrofining in order to prevent the formation of peroxides. «TC-1» may contain antioxidants by agreement. Antioxidants are compulsorily introduced into hydrotreated fuels («PT», «T- $6 »,\langle\mathrm{~T}-8 \mathrm{~B} »)$ to compensate the reduced chemical stability as a result of hydrofining. Antioxidants do not have any known side effects that could negatively affect the properties of fuel. The mechanism of antioxidants action is based on the idea that oxidation of hydrocarbons is a chain process, in which the origin of chains and their development occurs with the participation of free radicals. In other words, the action of oxidation inhibitors is aimed at preventing the formation of primary oxidation products - peroxides and consists in breaking and preventing the development of the oxidative reactions chain with the formation of hydroperoxide and stable free radical inhibitor:

$$
\mathrm{InH}+\mathrm{ROO} \rightarrow \mathrm{In}+\mathrm{ROOH} .
$$

In order to increase the antiwear (protective) properties of jet fuels the antiwear additives are used. Their main purpose is to increase the lubricating properties of fuel. Components of the engine fuel system and fuel regulation devices are designed to be lubricated by fuel. Differences in structures and materials of the fuel system components lead to different sensibilities of the equipment to the fuel lubricity. Aviation fuels, in turn, differ in their level of lubricity. The incipient operational problems are classified starting from cost reduction to the unplanned mechanical failure, which may cause the engine shutdown during flight. Physico-chemical 
properties of jet fuels do not provide sufficient lubricity of fuel at high temperatures and high loads. Hydrotreated jet fuels are characterized by worse lubricating properties than those obtained via direct distillation.

Antiwear additives are intended to restore the lubricating properties of fuels after hydrofining. They are introduced into fuel at the refineries along with antioxidants. Among the substances that improve antiwear properties are fatty and naphthenic acids, their esters and salts. Such components of antiwear additives as surfactants have the following properties:

- they improve the lubricating properties of petroleum products in relation to metals in the «petroleum product - water» system and slow the anode process of metal ionization; corrosion.

- they form strong chemosorption protective films on the metal surfaces that prevent

One of the widely used additives is the antiwear additive Hitec-580. It is a transparent amber-colored liquid with flash point $\geq 66^{\circ} \mathrm{C}$ and acid number of $80-100 \mathrm{mg} \mathrm{KOH} / \mathrm{g}$.

The purpose of this work was to study the efficiency and influence of antiwear additive Hitec-580 and antioxidants Agidol-1 and AO-80 on the properties of hydrotrated fraction of jet fuel.

For the experiments we used a hydrotreated fraction of jet fuel, the physico-chemical characteristics of which is presented in Table 1.

Table 1

Characteristics of hydrotreated fraction

\begin{tabular}{|c|c|}
\hline Indices & Values \\
\hline 1. Fractional composition, ${ }^{\circ} \mathrm{C}$ & 117 \\
\hline initial boiling point & 151 \\
\hline $10 \%$ & 166 \\
\hline $20 \%$ & 176 \\
\hline $30 \%$ & 185 \\
\hline $40 \%$ & $\mathbf{1 9 6}$ \\
\hline $\mathbf{5 0} \%$ & 203 \\
\hline $60 \%$ & 213 \\
\hline $70 \%$ & 221 \\
\hline $80 \%$ & 236 \\
\hline $90 \%$ & 245 \\
\hline $95 \%$ & 270 \\
\hline $98 \%$ & 0.037 \\
\hline Weight content of sulfur compounds, $\%$ & 37 \\
\hline Flash point, closed-cup, ${ }^{\circ} \mathrm{C}$ & 1.50 \\
\hline Viscosity at $20^{\circ} \mathrm{C}, \mathrm{mm}^{2} / \mathrm{s}$ & 19.2 \\
\hline Weight content of aromatic hydrocarbons, $\%$ & 0.002 \\
\hline Ash content, wt $\%$ & \\
\hline
\end{tabular}

Antioxidants Agidol-1 and AO-80 and antiwear additive Hitec-580 were used to determine their influence on jet fuel properties.

The additive Agidol-1 (Ionol, (2,6-di-tert-butyl-4-methylphenol) is a white crystalline powder without foreign impurities, with a melting point $\geq 69.5-70.0{ }^{\circ} \mathrm{C}$ and chilling point $\geq 69{ }^{\circ} \mathrm{C}$. This additive allows to completely prevent the oxidation of hydrogenation fuels, including that occurred at elevated temperatures (up to $150-160{ }^{\circ} \mathrm{C}$ ).

The additive AO-80 is an alkylphenolic antioxidant containing at least $75 \%$ of 2,4dimethyl-6-tert-butyl-phenol and maximum $25 \%$ of tert-butyl methyl and tert-butyl-dimethylphenol. Appearance - a colorless or yellowish-colored liquid that prevents the formation of resins, oxidation and prevention of peroxides formation during storage. 
Hitec-580 is the antiwear additive without phosphorus for low-sulfur aviation fuels used to reduce the wear of fuel pumps and regulators of aviation engines. It is a clear amber oily liquid with the density of $920 \mathrm{~kg} / \mathrm{m}^{3}$, pour point of mines $18{ }^{\circ} \mathrm{C}$, flash point $\geq 66^{\circ} \mathrm{C}$ and acid number of $80-100 \mathrm{mg} \mathrm{KOH} / \mathrm{g}$. Hitec-580 is a multicomponent mix, the main active substance of which is a dimer of linoleic acid.

Standard and analytical methods, as well as heuristic methods according to the Complex of Methods for Qualitative Assessment («KMKO») for jet fuels were used for the investigations.

At the first stage we tested hydrotreated fraction of jet fuel with different additives according to KMKO. The amounts of additives were chosen as maximum concentrations recommended by the manufacturer: Agidol-1 0.004 wt. \%; AO-80 0.0024 wt. \%; Hitec-580 0.004 wt. \%. The results of studies are presented in Table 2.

Results of testing the hydrotreated fraction of jet fuel according to KMKO

\begin{tabular}{|l|c|c|c|}
\hline \multirow{2}{*}{\multicolumn{1}{|c|}{ Indices }} & \multicolumn{3}{|c|}{ Fraction with additives } \\
\cline { 2 - 4 } & Agidol-1 & AO- 80 & Hitec-580 \\
\hline Compatibility with resins, \% & 0.54 & 0.43 & 0.58 \\
\hline Microbiological phase & \multicolumn{3}{|c|}{ a b s e c c e } \\
\hline Carbon number, carbon factor, NACA factor & 313.412 & 313.412 & 313.412 \\
\hline Opacity index SVI & 281.92 & 281.92 & 281.92 \\
\hline Luminometernumber & 59.5 & 59.5 & 59.5 \\
\hline Refraction index & 1.4426 & 1.4426 & 1.4423 \\
\hline Mechanical admixtures, wt. \% & a b s e n c e \\
\hline
\end{tabular}

Then we studied the influence of Agidol-1 (0.004 wt. \%) and AO-80 (0.0024 wt. \%) on the properties of hydrotreated fraction of jet fuel. The results are presented in Table 3.

The influence of Hitec-580 $(0.004 \mathrm{wt} . \%))$ on the properties of hydrotreated fraction of jet fuel is shown in Table 4.

At the last stage of research we compared the samples with different additives to evaluate the efficiency of additives and their influence on the quality performance of commercial aviation fuel. The samples contain the following mixture of additives:

- antiwear additive Hitec-580 and antioxidant Agidol-1;

- antiwear additive Hitec-580 and antioxidant AO-80.

The research results are presented in Table 5.

Table 3

Properties of hydrotreated fraction of jet fuel with additives Agidol-1 (0.004 wt. \%) and AO-80 (0.0024 wt. \%)

\begin{tabular}{|c|c|c|c|c|}
\hline \multirow[b]{2}{*}{ No. } & \multirow[b]{2}{*}{ Indices } & \multicolumn{2}{|c|}{ Experimental results } & Standard values \\
\hline & & $\begin{array}{l}\text { Hydrotreated } \\
\text { fraction with } \\
\text { Agidol-1 }\end{array}$ & $\begin{array}{l}\text { Hydrotreated } \\
\text { fraction with } \\
\text { AO- } 80\end{array}$ & $\begin{array}{c}\text { RT (GSTU } \\
320.00149943 . \\
007-97)\end{array}$ \\
\hline 1 & 2 & 3 & 4 & 5 \\
\hline 1 & Acidity, $\mathrm{mg} \mathrm{KOH}$ per $100 \mathrm{~cm}^{3}$ of fuel & 0.184 & 0.18 & No more than 0.7 \\
\hline 2 & Acidnumber, mg KOH per 1 gof fuel & 0.046 & 0.046 & - \\
\hline 3 & Existentgum content, $\mathrm{mg}$ per $100 \mathrm{~cm}^{3}$ of fuel & 1.22 & 1.08 & No more than 4 \\
\hline 4 & $\begin{array}{l}\text { Corrosiveness to copper strip at } 100^{\circ} \mathrm{C} \text { for } 3 \\
\text { hours }\end{array}$ & stand the test & stand the test & stand the test \\
\hline \multirow[b]{2}{*}{5} & \multicolumn{4}{|c|}{ Thermal oxidative stability under static conditions at $150^{\circ} \mathrm{C}$} \\
\hline & $\begin{array}{l}\text { weight content of deposit, } \\
\mathrm{mg} \text { per } 100 \mathrm{~cm}^{3} \text { of fuel }\end{array}$ & 1.64 & 1.6 & No more than 6 \\
\hline
\end{tabular}


Table 3 continue

\begin{tabular}{|c|c|c|c|c|}
\hline 1 & 2 & 3 & 4 & 5 \\
\hline 6 & Water soluble acids and alkali & absence & absence & absence \\
\hline 7 & Mechanical admixtures and water & absence & absence & absence \\
\hline \multirow[b]{3}{*}{8} & \multicolumn{4}{|c|}{ Thermal oxidative stability JFTOT at the control temperature below $260{ }^{\circ} \mathrm{C}$} \\
\hline & a) differential pressure of filter, $\mathrm{kPa}$ & 0 & 0 & - \\
\hline & $\begin{array}{l}\text { b) color of deposits over tube according to the } \\
\text { color scale (in the absence of non-typical } \\
\text { deposits), points }\end{array}$ & 1 & 1 & - \\
\hline \multirow{3}{*}{9} & \multicolumn{4}{|c|}{ High-temperature corrosion, mass loss during test, $\mathrm{g} / \mathrm{m}^{2}$, at $120^{\circ} \mathrm{C}$} \\
\hline & for copper & 0.47 & 0.44 & No more than 3.0 \\
\hline & for bronze & 0.42 & 0.38 & No more than 2.5 \\
\hline 10 & Compatibility with resins, $\%$ & 0.54 & 0.43 & - \\
\hline \multirow[t]{2}{*}{11} & \multicolumn{4}{|l|}{ Specific electric conductivity, $\mathrm{pS} / \mathrm{m}$} \\
\hline & - without antistatic additive at $20^{\circ} \mathrm{C}$ & 3 & 3 & 10 \\
\hline
\end{tabular}

The influence of on the Properties of hydrotreated fraction of jet fuel with the additive Hitec-580 (0.004 wt. \%)

\begin{tabular}{|c|c|c|c|}
\hline \multirow[b]{2}{*}{ No. } & \multirow[b]{2}{*}{ Indices } & Experimental results & Standard values \\
\hline & & $\begin{array}{l}\text { Hydrotreated fraction with } \\
\qquad \text { AO- } 80\end{array}$ & $\begin{array}{c}\text { RT (GSTU 320.00149943. } \\
\text { 007-97) }\end{array}$ \\
\hline 1 & Weight part of total sulfur, $\%$ & 0.002 & No more than 0.25 \\
\hline \multirow[t]{4}{*}{2} & \multicolumn{3}{|l|}{ Kinematic viscosity, $\mathrm{mm}^{2} / \mathrm{s}$} \\
\hline & - at $20^{\circ} \mathrm{C}$ & 1.54 & No less than 1.25 \\
\hline & - at minus $40^{\circ} \mathrm{C}$ & 6.9 & No more than 16 \\
\hline & - at minus $20^{\circ} \mathrm{C}$ & - & - \\
\hline 3 & Mechanical admixtures and water & absence & absence \\
\hline 4 & $\begin{array}{l}\text { Mechanical admixtures, } \% \text { according } \\
\text { to GOST } 10577\end{array}$ & absence & 0.0003 \\
\hline \multirow{3}{*}{5} & \multicolumn{3}{|c|}{ Antiwear properties under sliding friction at the device UPS-01 } \\
\hline & - antiwear properties criterion, $\%$ & 132 & No less than 95 \\
\hline & - wear spot diameter, mm & - & - \\
\hline
\end{tabular}

Properties of hydrotreated fraction of jet fuel with the mixture of additives

\begin{tabular}{|c|c|c|c|}
\hline \multirow[b]{2}{*}{ No } & \multirow[b]{2}{*}{ Indices } & \multicolumn{2}{|c|}{ Samples } \\
\hline & & $\begin{array}{c}\text { Fraction + Hitec-580 (0.003 wt. } \\
\%)+ \text { Agidol-1 (0.003 wt. } \%)\end{array}$ & $\begin{array}{c}\text { Fraction + Hitec-580 (0.003 wt. } \\
\quad \%)+\mathrm{AO}-80\left(17 \mathrm{mg} / \mathrm{dm}^{3}\right)\end{array}$ \\
\hline 1 & 2 & 3 & 4 \\
\hline \multirow{2}{*}{1} & \multicolumn{3}{|l|}{ Density, $\mathrm{kg} / \mathrm{m}^{3}$} \\
\hline & - at $20^{\circ} \mathrm{C}$ & 789 & 789 \\
\hline \multirow[t]{6}{*}{2} & \multicolumn{3}{|l|}{ Fractional composition, ${ }^{\circ} \mathrm{C}$} \\
\hline & initial boiling point & 147.2 & 146.7 \\
\hline & $10 \%$ & 172.5 & 171.1 \\
\hline & $50 \%$ & 189.4 & 188.4 \\
\hline & $90 \%$ & 214.4 & 212.2 \\
\hline & $98 \%$ & 239.8 & 227.2 \\
\hline \multirow[t]{2}{*}{3} & \multicolumn{3}{|l|}{ Kinematic viscosity, $\mathrm{mm}^{2} / \mathrm{s}$} \\
\hline & $-\quad$ at $20^{\circ} \mathrm{C}$ & 1.57 & 1.59 \\
\hline
\end{tabular}


Table 5 continue

\begin{tabular}{|c|c|c|c|}
\hline 1 & 2 & 3 & 4 \\
\hline & - $\quad$ at minus $40^{\circ} \mathrm{C}$ & 6.95 & 6.95 \\
\hline 4 & Low heat value, $\mathrm{kJ} / \mathrm{kg}$ & 43363.84 & 43363.84 \\
\hline 5 & $\begin{array}{l}\text { Acidity, mg KOH per } 100 \mathrm{~cm}^{3} \\
\text { of fuel }\end{array}$ & 0.38 & 0.4 \\
\hline 6 & $\begin{array}{l}\text { Acid number, mg KOH per } 1 \mathrm{~g} \\
\text { of fuel }\end{array}$ & 0.062 & 0.063 \\
\hline 7 & Flash point, closed-cup, ${ }^{\circ} \mathrm{C}$ & 51 & 48 \\
\hline 6 & Chilling point, ${ }^{\circ} \mathrm{C}$ & minus 60.5 & minus 61 \\
\hline \multirow[t]{2}{*}{7} & \multicolumn{3}{|c|}{ Thermal oxidative stability under static conditions at $150^{\circ} \mathrm{C}$} \\
\hline & $\begin{array}{l}\text { weight content of deposit, } \\
\text { mg per } 100 \mathrm{~cm}^{3} \text { of fuel }\end{array}$ & 1.6 & 1.48 \\
\hline 8 & $\begin{array}{l}\text { Weight content of aromatic } \\
\text { hydrocarbons, } \%\end{array}$ & 17.5 & 17.5 \\
\hline 9 & $\begin{array}{l}\text { Existentgum content, mg per } \\
100 \mathrm{~cm}^{3} \text { of fuel }\end{array}$ & 1.65 & 1.25 \\
\hline 10 & Weight content of total sulfur, $\%$ & 0.0015 & 0.0012 \\
\hline 11 & $\begin{array}{l}\text { Corrosiveness to copper strip at } \\
100^{\circ} \mathrm{C} \text { for } 3 \text { hours }\end{array}$ & stands the test & stands the test \\
\hline 12 & Water soluble acids and alkali & absence & absence \\
\hline 13 & Mechanical admixtures and water & absence & absence \\
\hline 14 & $\begin{array}{l}\text { Reaction with water, points, } \\
\text { - state of interface }\end{array}$ & 1 & 1 \\
\hline \multirow[t]{2}{*}{15} & \multicolumn{3}{|l|}{ Specific electric conductivity, $\mathrm{pS} / \mathrm{m}$} \\
\hline & $\begin{array}{l}\text { - without antistatic additive } \\
\text { at } 20^{\circ} \mathrm{C}\end{array}$ & 2.4 & 2.8 \\
\hline \multirow[t]{3}{*}{16} & \multicolumn{3}{|c|}{ Thermal oxidative stability JFTOT at the control temperature below $260^{\circ} \mathrm{C}$} \\
\hline & $\begin{array}{l}\text { a) differential pressure of filter, } \\
\mathrm{kPa}\end{array}$ & 0 & 0 \\
\hline & $\begin{array}{l}\text { b) color of deposits over tube } \\
\text { according to the color scale (in the } \\
\text { absence of non-typical deposits), } \\
\text { points }\end{array}$ & 1 & 1 \\
\hline \multirow[t]{2}{*}{17} & \multicolumn{3}{|c|}{ Antiwear properties under sliding friction at the device UPS-01 } \\
\hline & antiwear properties criterion, $\%$ & 137 & 134 \\
\hline \multirow[t]{3}{*}{18} & \multicolumn{3}{|c|}{ High-temperature corrosion, mass loss during test, $\mathrm{g} / \mathrm{m}^{2}$, at $120^{\circ} \mathrm{C}$} \\
\hline & for copper & 19.2 & 31.2 \\
\hline & for bronze & 0.92 & 2.0 \\
\hline 19 & Compatibility with resins, $\%$ & 0.58 & 0.59 \\
\hline 20 & Microbiological phase & absence & absence \\
\hline 21 & $\begin{array}{l}\text { Carbon number, carbon factor, } \\
\text { NACA factor }\end{array}$ & 310.213 & 309.51 \\
\hline 22 & Opacity index SVI & 283.17 & 278.23 \\
\hline 23 & Luminometernumber & 59.48 & 59.48 \\
\hline 24 & Refraction index & 1.4425 & 1.4425 \\
\hline 25 & Mechanical admixtures, wt. \% & absence & absence \\
\hline 26 & Content of antioxidant, wt. \% & 0.003 & 0.002 \\
\hline
\end{tabular}

The experimental results show that introduction of Agidol-1 in amount of 0.004 wt. \% does not significantly affect the properties of the hydrotreated fraction of jet fuel. At the same time, if we compare the samples with different amount of Agidol-1, we observed the decrease in the existent 
gum content. This value is $1.25 \mathrm{mg}$ per $100 \mathrm{~cm}^{3}$ of fuel (for Agidol-1 in amount of $0.003 \mathrm{wt} \%$ ) versus $1.22 \mathrm{mg}$ per $100 \mathrm{~cm}^{3}$ of fuel (for Agidol-1 in amount of $0.004 \mathrm{wt}$. \%). Moreover, a slight decrease in the corrosive effect of the fuel with 0.004 wt. \% of Agidol-1 was observed as well.

Antiwear properties of jet fuels were determined by a set of physico-chemical indices, in particular: the kinematic viscosity at $20^{\circ} \mathrm{C}$ and minus $40{ }^{\circ} \mathrm{C}$, the mass fraction of total sulfur, the content of mechanical admixtures and water, antiwear properties under sliding friction at the device UPS-01. For all of these parameters, the samples with antiwear additive Hitec-580 in various concentrations fully meet the requirements of the regulatory document for jet fuel (GSTU 320.00149943.007-97 «Fuel for jet engines «PT». Specifications»).

The introduction of AO-80 in amount of $0.0024 \mathrm{mg} / \mathrm{l}$ shows a positive effect on the properties of the fuel fraction, which characterizes its chemical and thermal oxidative stability. These samples fully meet the requirements of the regulatory document for jet fuel (GSTU 320.00149943.007-97 «Fuel for jet engines «PT». Specifications»)).

The additive AO-80 has a positive effect on thermal oxidative stability of fuel under static conditions. So, the weight content of the formed deposit was $1.6 \mathrm{mg}$ per $100 \mathrm{~cm}^{3}$ of fuel. It should be noted that existent gum content in the samples with AO-80 significantly decreased and amounted to 1.0 and 1.08 per $100 \mathrm{~m}^{3}$ of fuel. This indicates the efficiency of AO- 80 .

The additive AO- 80 has also a positive influence on corrosion properties of fuel. There is a significant decrease in the corrosive effect on both copper and bronze of the fuel with a minimum content of additive to compare with the sample with the maximum concentration of AO- 80 .

The experimental results of hydrotreated fraction of jet fuel with a mixture of additives showed ambiguous effect on the quality parameters of the fraction. It should be noted that the use of antiwear and antioxidant additives in the mixture does not have a negative effect on the quality parameters. The positive influence is observed relative to the antiwear properties. Thus, the antiwear properties criterion for the sample + Hitec-580 + Agidol-1 increased in comparison with the sample + Hitec-580 + AO-80. Such values as existent gum content and thermal oxidative stability under static and dynamic conditions had not essential differences. The difference was within the limits of the error. A slight increase in acidity (acid number) of the samples was observed. However, their numerical values were within the limits defined by the normative documentation.

We observed a significant loss in the sample mass during the experiments indicating the corrosive effect of the samples on copper and bronze compared with the samples with antioxidant additives only. In general, the results show the need for more detailed studies of the influence of the complex application of application packages on the properties of fuels for air jet engines.

A comparative study of the hydrotreated fraction of jet fuel with antioxidants and Hitec-580 was carried out. The efficiency of additives and their influence on the quality of commercial aviation fuel were evaluated.

The results show the effectiveness of the antiwear additive Hitec-580 in the maximal amount recommended by the manufacturer. The antioxidant Agidol-1 exibits low antioxidative effect but it does not have a negative effect on the quality of commercial jet fuel, which meets the requirements of regulatory document GSTU 320.00149943.007-97 «Fuel for jet engines «PT». Specifications».

The antioxidant AO-80 is effective as an inhibitor of oxidation. It also does not have a negative effect on the quality of commercial jet fuel, which meets the requirements of regulatory document GSTU 320.00149943.007-97 «Fuel for jet engines «PT». Specifications».

It is recommended to conduct more detailed studies on the complex influence of the additives on the properties of jet fuels, in particular in the conditions of long-term storage, as well as studies on the possibility of expanding the range of antiwear and antioxidant additives for jet fuels. 


\author{
PЕФЕРАТ \\ Сергій Бойченко ${ }^{1}$, Юрій Голич ${ }^{2}$, Анна Яковлєва ${ }^{3}$, Ірина Шкільнюк ${ }^{3}$, \\ Петро Топільницький ${ }^{4}$, Вікторія Романчук ${ }^{4}$, Olufemi Babatunde ${ }^{3}$ \\ ${ }^{l}$ Факультет будови машин і авіачіi \\ Жешувського технологічного університету, \\ ${ }^{2} \Pi$ ПАТ «Кктатнафта», golich@ukrtatnafta.com, \\ ${ }^{3}$ Hаціональний авіаційний університет, a.v.iakovlieva@ukr.net, \\ ${ }^{4}$ Національний університет «Львівська політехніка», topoil@polynet.lviv.ua \\ ВПЛИВ АНТИОКСИДАНТІВ І ПРОТИЗНОШУВАЛЬНИХ ДОДАТКІВ \\ НА ВЛАСТИВОСТІ ПАЛИВ ДЛЯ РЕАКТИВНИХ ЛІТАКІВ
}

Стаття присвячена вивченню впливу протиокиснювальних та протизношувальних додатків на реактивне паливо. До гідроочищеної фракції палива для повітряно-реактивних двигунів додавали протиокиснювальні додатки Агідол-1, АО-80 та протизношувальний додаток Хайтек-580 у концентраціях, рекомендованих виробником. Встановлено, що додавання цих присадок, як окремо, так і в комплексі, покращує фізико-хімічні властивості товарного палива для паливно-реактивних двигунів, не чинить на нього негативного впливу, а його показники відповідають вимогам нормативних документів.

Ключові слова: реактивне паливо, термоокиснювальна стабільність, протиокиснювальні додатки, протозношувальні додатки

\author{
PЕФЕРАТ \\ Сергей Бойченко ${ }^{1}$ Юрий Голич ${ }^{2}$, Анна Яковлева ${ }^{3}$, Ирина Шкильнюк ${ }^{3}$, \\ Петр Топильниикий, Виктория Романчук ${ }^{4}$, Olufemi Babatunde ${ }^{3}$ \\ ${ }^{l}$ Факультет конструкиии машин и авиации \\ Жешувского технологического университета, sboichen@prz.edu.pl, \\ ${ }^{2}$ ПАО "Укртатнафта", golich@ukrtatnafta.com, \\ ${ }^{3}$ Национальный авиационный университет, chemmotology@ukr.net, \\ ${ }^{4}$ Национальный университет «Львовская политехника», topoil@polynet.lviv.ua \\ ВЛИЯНИЕ АНТИОКСИДАНТОВ И ПРОТИВОЗНИСНЫХ ПРИСАДОК \\ НА СВОЙСТВА ТОПЛИВ ДЛЯ РЕАКТИВНЫХ САМОЛЕТОВ
}

Статья посвящена изучению влияния противокислительных и противоизносных добавок на реактивное топливо. Во фракцию топлива для воздушно-реактивних двигателей гидроочищенного добавляли противокислительны добавки Агидол-1, АО-80 и противоизносную добавку Хайтек-580 в концентрациях, рекомендованных производителем. Установлено, что добавление этих присадок, как отдельно так и в комплексе, улучшает физико-химические свойства товарного топлива для топливнореактивных двигателей, не оказывает на него негативного влияния, а его показатели соответствуют требованиям нормативных документов.

Ключевые слова: реактивное топливо, термоокислительная стабильность, противокислительные добавки, противоизносные добавки

$$
\begin{aligned}
& \text { ABSTRACT } \\
& \text { Sergii Boichenko }{ }^{1} \text {, Yuri Golych }{ }^{2} \text {, Anna Iakovlieva }{ }^{3} \text {, Iryna Shkilniuk }{ }^{3} \text {, } \\
& \text { Petro Topilnytskyi }{ }^{4} \text {,Victoriia Romanchuk }{ }^{4} \text {, Olufemi Babatunde }{ }^{3} \\
& { }^{I} \text { Faculty of Mechanical Engineering and Aeronautics } \\
& \text { of Rzeszow University of Technology, sboichen@prz.edu.pl, } \\
& { }^{2} J S C \text { «Ukrtatnafta»,golich@ukrtatnafta.com, } \\
& { }^{3} \text { National Aviation University, chemmotology@ukr.net, } \\
& { }^{4} \text { National University «Lvivska Polytechnica»,topoil@polynet.lviv.ua }
\end{aligned}
$$

\title{
INFLUENCE OF ANTIOXIDANTS AND ANTIWEAR ADDITIVES ON JET FUEL PROPERTIES
}

The article is devoted to the study of antioxidants and antiwear additives influence on reactive fuels. The antioxidants Agidol-1, AO- 80 and antiwear Hitec-580 were added to the hydrotreated fuel fraction for airjet engines in the concentrations recommended by the manufacturer. It was established that the addition of these additives, both individually and in combination, improves the physical and chemical properties of commercial fuel for fuel-jet engines, does not affect it, and its properties meet the requirements of normative documents.

Key words: reactive fuel, thermal oxidative stability, antioxidant additives, antiwear additives. 


\title{
REFERENCES
}

1. Chemical world [Electronic reference]. - Access mode: https://chemworld.com.ua/index.php/naftokhimiia7/44-yakist-paliv-dlya-reaktivnikh-dviguniv.

2. Motor fuels: properties and quality. Textbook / S. Boychenko, A. Puschak, P. Tollynitsky, K. Leida; ed.by

S. Boichenko. - K.: «Center for Educational Literature», 2017. - 324 p.

3. Index Mundi Live Clocks [Electronic reference]. - Access mode: http:// www.indexmundi.com.

4. Wings: everything about Ukrainian aviation [Electronic reference]. - Access mode:

http://www.wing.com.ua.

5. Kapustin V.M. Petroleum and alternative fuels with additives and addition agents / B.M. Kapustin. - Moscow: KolosS, 2008. -232 p.

6. Kapustin V.M. Chemistry and technology of oil refining / V.M. Kapustin, M.G. Rudin. - M.: Khimiya, 2013. $-496 \mathrm{p}$.

7. Aviation chemmotology: fuels for aircraft engines. Theoretical and engineering bases of application: textbook / [N.S. Kulik, A.F. Aksenov, L.S. Yanovsky, S.V. Boychenko et al.]. - K.: NAU, 2015. - 560 p.

8. Iakovlieva A.V. Overview of innovative technologies for aviation fuels production / A.V. Iakovlieva, S.V. Boichenko, O.O. Vovk // Chemistry and Chemical Technology. - 2013. - Vol.7. - No 3. - P. 305-312.

9. Iakovlieva A.V. Implementation of garnisized technical requirements for the quality of aviation gasoline and fuel for jet engines / A.V.Iakovlieva, S.V. Boichenko, I.O. Shkilnyuk // Energy technologies and energy saving. -2016 . - №1. - P.23-31.

DOI: doi.org/10.18372/38224

UDC: 621.436-634:502.17

\subsection{NITROGEN OXIDE AND DISPERSE PARTICLES EMISSION REDUCTION IN DIESEL ENGINES}

\author{
Georgy Kuharyonok, Denis Kapsky, Vitaly Berezun
}

Constant toughening of requirements for diesels has directed the development of the world engine manufacturing to improving ecological indeces. The major difficulty for diesel enginebuilding is nitrogen oxide (NOx) and particles mater (PM) emission reduction. Their level limit is determined by the requirements of technical guidelines. Concerning available at the moment technologies, the strategy of emission reduction (ER) is conditioned by the compromise between the degree of diesel design complexity and fume cleaning efficiency $[1,2,3]$.

Among the factors considered above the following parameters are worth mentioning: the injection pressure, the fuel injection advance angle and the exhaust fume recycle rate for reasons of the major influence on fume emission and the fuel-economic indicator. At the same time the effective value range shift of varying parameters is determined by the basic diesel engine design parameters. The use of injection systems allows to control flexibly the injection pressure and the fuel injection advance angle without making the engine design too complex. Together with the use of the exhaust gas recirculation (EGR) system the injection systems allow to coordinate design parameters and engine-on mode specifications.

The improving potential of diesel engine operating cycle is currently not exhausted: it is the main means of attaining up-to-date regulated markers, which makes the research of the fume emission reduction potential by means of improving engine workflows relevant and requested.

The most difficult task for diesel engines is to meet the requirements of $\mathrm{NO}_{\mathrm{x}}$ and $\mathrm{PM}$ emission reduction [3].

The purpose of the research is to reduce the so called "unrefined" NOx and PM emission by means of choosing design and adjustment parameters of diesel engines workflows taking into account the priority of fuel economy. 